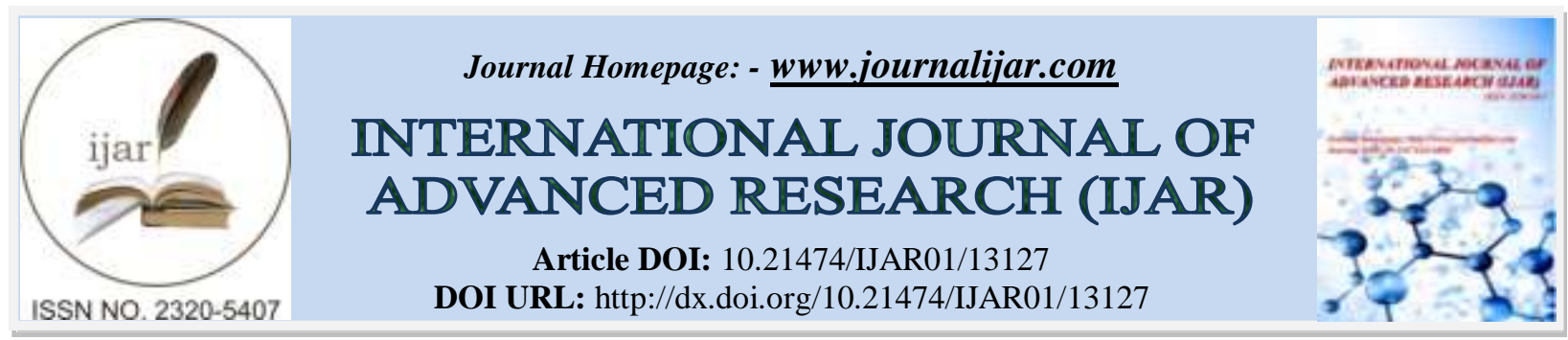

RESEARCH ARTICLE

\title{
A COMPARATIVE STUDY ASSESSING THE DIFFERENT PATTERNS OF RADIATION REACTIONS IN HEAD AND NECKCANCER PATIENTS UNDERGOING RADIATION THERAPY AT DIFFERENT TIMES OF THE DAY-IN THE MORNING VERSUS EVENING
}

\author{
Dulasi Raman Ponna ${ }^{1}$, Yumkhaibam Sobita Devi' ${ }^{2}$ Kishalay Baidya ${ }^{2}$, Laishram Jaichand Singh ${ }^{2}$, \\ Ningthoujam Dinita Devi' ${ }^{2}$ and Silchang K. Marak ${ }^{2}$ \\ 1. Tiruvarur Medical Centre, Tiruvarur, Tamil Nadu, India. \\ 2. Department of RadiationOncology, RIMS, Imphal, Manipur, India.
}

\section{Manuscript Info}

Manuscript History

Received: 10 May 2021

Final Accepted: 14 June 2021

Published: July 2021

Key words:-

Radiation, Toxicity, Chronotherapy,

Mucositis

\begin{abstract}
Background: Human oral mucosa, is a prime target for radiation induced toxicity in patients undergoing radiotherapy for head and neck cancer. The oral cavity is highly susceptible to direct and indirect toxic effects of cancer chemotherapy and ionizing radiation. In our study we investigated the role of chronotherapy with respect to radiation induced mucositis occurring in the normal oral mucosa and treatment response in tumor tissue in cancer patients undergoing radiation therapy to head and neck region.

Materials and Methods: This non-randomized clinical study was done to compare the two different timing schedules in the management of head and neck cancer by external beam radiation therapy by cobalt -60 (Theratron780C). In morning arm (arm A), Patients received external beam radiotherapy (EBRT) by cobalt-60 with SSD of $80 \mathrm{~cm}$ with daily fractions, five days a week, between 8AM-10 AM whereas in evening arm (arm B), patients received EBRT by cobalt-60 with daily fractions, five days a week, between 3PM-5 PM. Both the arms received same radiation regimen.

Results: The study concluded that in the morning arm the onset of oral mucositis was observed to be significantly delayed and the duration of mucositis was also significantly shorter as compared to the evening arm. Statistically significant difference in severity of mucositis was found between the two arms.

Conclusion: Since there is no active measure to minimize normal tissue toxicity, chronomodulated radiotherapy would be a feasible and cost effective treatment strategy that can be put into clinical practice.
\end{abstract}

Copy Right, IJAR, 2021,. All rights reserved.

\section{Introduction:-}

The term "Head and Neck Malignancies" usually refers to the variety of neoplasms arising from upper aerodigestive tract. ${ }^{1}$ Ninety percent of head and neck malignancies are squamous cell carcinomas. ${ }^{2}$ Head and neck cancers represent the sixth most common cancer worldwide with approximately 650000 new patients diagnosed annually resulting in more than 330000 deaths every year. It is accounting for approximately $6 \%$ of all cancer cases and 1-2\% of all cancer deaths. Oral cavity and laryngeal cancers are the most common head and neck cancers globally. ${ }^{3}$ 
Historically, Head and neck squamous cell carcinoma (HNSCC) have been a disease of older males with heavy lifelong tobacco use, high alcohol consumption, poorly preserved diet, and bad dentition. As smoking increased among women, the male to female ratio of $5: 1$ observed in 1960 s declined to $3: 1$ as of present. Infection with highrisk HPV has also been implicated in the pathogenesis of growing subset of HNSCCs. ${ }^{4}$

In patients with early stage head and neck squamous cell carcinoma, single-modality treatment with surgery or radiotherapy (RT) remains the therapy of choice. RT is an option in early stage cancer as either external beam or brachytherapy, however in this setting, RT is limited by xerostomia, mucositis, and osteoradionecrosis.

The mucosal lining of the gastrointestinal tract, including the oral mucosa, is a prime target for treatment-related toxicity. The oral cavity is highly susceptible to direct and indirect toxic effects of ionizing radiation. ${ }^{6}$ Acute mucositis results from the loss of squamous epithelial cells owing to the sterilization of mucosa stem cells and the inhibition of transit cell proliferation. This leads to a gradual linear decrease in epithelial cell numbers. Normally, cells of the mouth undergo rapid renewal over a 7-14 days cycle. Radiation therapy interferes with cellular mitosis and reduces the ability of the oral mucosa to regenerate. ${ }^{7}$

Management of oral mucositis has been largely palliative to date. Various guidelines are being followed which include Mucositis Study Group of the Multinational Association for Supportive Care in Cancer and the International Society of Oral Oncology (MASCC/ISOO) guidelines for the management of mucositis and RTOG guidelines. ${ }^{8}$

Chronotherapy refers to the use of circadian, ultradian, infradian \& seasonal or other rhythmic cycles in the application of therapy. The goal of chronotherapy is to take into account the biological clock of various tissues in trying to schedule treatment in the most opportune time for the tumor and the least harmful time for the normal cells. Therefore, investigating the peak times of oral mucosa cells could dictate the timing of treatment to diminish side effects. ${ }^{9}$

In the normal human oral mucosa, a significant circadian rhythm was found for all studied proteins, with the high point of expression for p27 at 6:00 AM (early G1-phase marker), p53 at 10:50 AM (late G1- phase marker), cyclin-E at 2:50 PM (S-phase marker), cyclin-A at 4:00 PM (G2-phase marker), and cyclin-B1 at 9:10 PM (M-phase marker). ${ }^{10}$ During this time, normal cells would receive better protection, as they peak in G1. ${ }^{11}$ The best treatment time for inducing apoptosis was in the late activity phase, coinciding with a time when most target cells were in the G2-M phase. ${ }^{12}$ Henceforth the ideal time of the day to treat a tumor, would be in the morning hours , to maximize tumor kill as the cells would be more or less in the radiosensitive G2/M phase and the normal cells would be minimally affected as they would be cycling in the radio resistant G1 phase. ${ }^{13}$

\section{Materials And Methods:-}

A non-randomized interventional study was undertaken in the Department of Radiotherapy, Regional Institute of Medical Sciences, Imphal, Manipur for a period of 24 months starting from September 2015 to August 2017 to study the feasibility of comparison of different patterns of radiation reactions in Head and Neck cancer patients undergoing radiation therapy at different times of the day - in the Morning versus Evening. Ethical approval was obtained from Institutional Ethics Committee, RIMS, Imphal before study. Written informed consent was obtained from the participating individuals.

Patients aged between 30-70 years with histopathologically confirmed cases (epithelial tumours) of head and neck cancer with Karnofsky Performance Status (KPS) $\geq 60 \%$,Haemoglobin $\geq 10 \mathrm{gm} \%$,TLC $\geq 4000 / \mathrm{mm} 3$, Platelet count $\geq 100,000 / \mathrm{mm} 3$, normal Kidney Function Test, Liver Function Test, Blood sugar, normal ECG, patients willing to remain on follow up after radiation therapy till the study is completed and willing to participate in this study were inclusion criteria for this study.

This study was done to compare the two different timing schedules in the management of head and neck cancer by external beam radiation therapy by cobalt-60 (Theratron780C). In Morning Arm (Arm A), Patients received external beam radiotherapy (EBRT) by cobalt-60 with SSD of $80 \mathrm{~cm}$ with daily fractions, five days a week, between $8 \mathrm{AM}-10$ AM whereas in Evening Arm (Arm B),Patients received external beam radiotherapy (EBRT) by cobalt-60 with SSD of $80 \mathrm{~cm}$ with daily fractions, five days a week, between 3PM-5 PM. Both the arms received same radiation regimen. Treatment planning was done in the conventional method by using CECT neck. The head and neck radiation portals included atleast half of the oral mucosa and oropharynx. Patients received 66-70Gy in 30-35 
fractions (200cGy/fraction/day) depending on the disease site by shrinking field technique. During the whole period of treatment, patients were assessed for radiation reactions every week and the tumour response was assessed 1 month post completion of treatment. Treatment related toxicities was assessed in accordance with Radiation Therapy Oncology Group [RTOG] Criteria.Tumor response was evaluated by clinical evaluation and imaging studies after 1 month of completion of treatment and late response was assessed at 6 months after the completion of treatment using RECIST Criteria and followed up till study completion.

\section{Statistical Analysis:}

Data was entered and analyzed using SPSS version 21. Descriptive statistics like age, sex etc was presented as mean and onset, grade of mucositis, etc., were presented as percentages. Chi-square was used to determine the association of the treatment regimen with the treatment response and grade of mucositis. The severity of oral mucositis was assessed by Fisher exact test. The median duration of oral mucositis was determined by independent t-test. Kaplan Meier survival analysis was used to assess the late treatment outcome. p value $<0.05$ was considered as significant.

\section{Results:- \\ Patient's characteristics}

From September 2015 to August 2017, 124 patients were recruited and randomly assigned into two treatment arms, Arm I (morning arm) with 62 patients and Arm II (evening arm) with 62 patients. The median age at diagnosis was found to be 54 years (range $=31-68$ years). In regard to the age distribution among the two arms, it was found that the maximum number of patients were in the age group of 51 to 60 years, $25(40.3 \%)$ and 23 patients (37.1\%) in respective arms. The number of patients in age group 41-50 years were $18(29 \%)$ and 19 (30.6\%) patients. The number of patients in age group 31-40 years were $07(11.3 \%)$ and $08(12.9 \%)$ patients. The number of patients in age group 61-70 years were $12(19.4 \%)$ in both arms ( $\mathrm{p}$ value $=0.98$ ).

Out of 124 patients accrued for the study, $84(67.7 \%)$ were males and $40(32.2 \%)$ were female with a male to female ratio of 2.1:1. On sub-group analysis, there were $46(74.2 \%)$ males and $16(25.8 \%)$ females in the morning arm and $38(61.3 \%)$ males and $24(38.7 \%)$ females in the evening arm.Out of 124 patients, $85(68.5 \%)$ were smokers or had previous history of smoking and $39(31.5 \%)$ were non-smokers with a smokers to non-smokers ratio of 2.1:1. (p value $=0.176$ ). Maximum patients in both the arms had KPS of $80 \%, 31(50 \%)$ patients in the morning arm and 31 (50\%) patients in the evening arm, followed by KPS $70 \%$ in 19 patients $(30.6 \%)$ and 18 patients $(29.0 \%)$ KPS of $90 \%$ was seen in $9(14.5 \%)$ patients and $5(8.1 \%)$ patients. KPS of $60 \%$ was seen $3(4.8 \%)$ and $8(12.9 \%)$ patients.

\section{Tumor Characteristics:}

Overall, the most common primary site was found to be carcinoma nasopharynx in $45(36.6 \%)$ patients followed by carcinoma of oral cavity in $33(26.6 \%)$ patients and hypopharynx in $17(13.7 \%)$ patients. The most common histopathology found was squamous cell carcinoma in $78(62.9 \%)$ patients followed by undifferentiated carcinoma in $31(25 \%)$ patients.

Overall, $71(57.3 \%)$ patients had Stage 1 disease and $53(42.7 \%)$ patients had Stage 2 disease. In the morning arm 36 (58.1\%) patients were in Stage 1 disease and 26 (41.9\%) patients in Stage 2 disease. In the evening arm $35(56.5 \%)$ patients had Stage 1 disease and $27(43.5 \%)$ patients had Stage 2 disease.

\section{Toxicity and treatment response:}

The onset of radiation induced oral mucositis was taken as the appearance of erythema of the oral mucosa included in the radiation field as per the RTOG guidelines. Examination of the patient was done at the baseline and at the end of each week.

The development of mucositis was seen in $91.9 \%$ in the morning arm and $98.4 \%$ in the evening arm. The appearance of oral mucositis at the end of second week was seen in $32(51.6 \%)$ patients in morning arm and 52 $(83.9 \%)$ patients in the evening arm, which was found to be statistically significant $(\mathrm{p}=0.000)$. By the end of the treatment $55(88.7 \%)$ patients developed oral mucositis in the morning arm and $61(98.4 \%)$ patients developed oral mucositis (Table 1).

The severity of oral mucositis observed during the entire period of treatment in the morning arm was $8.1 \%$ grade $0,19.4 \%$ grade $1,45.2 \%$ grade $2,25.8 \%$ grade 3 and $1.6 \%$ grade 4 . In the evening arm, it was $1.6 \%$ grade 0 , $6.5 \%$ grade $1,32.3 \%$ grade $2,46.8 \%$ grade 3 and $12.9 \%$ of grade 4 . The severity of mucositis was comparable 
between the two arms, it was found that grade 3 and grade 4 mucositis was found statistically significant with $\mathrm{p}=0.024$ and $\mathrm{p}=0.017$ respectively (Table 2 ). The median time to develop grade 3 or grade 4 mucositis was found to 4.7 weeks in the morning arm and 5.8 weeks in the evening arm and p value was found to be statistically significant $(\mathrm{p}=0.013)$ (Table 3$)$.

Patients who were smokers or had previous history of smoking had significant grade 3 oral mucositis and the p value was found to be significant ( $\mathrm{p}=0.005)$. But for the grade 4 mucositis among smokers, the $\mathrm{p}$ value was not found to be significant $(\mathrm{p}=0.115)$.

Response assessment was done 1 month after the completion of treatment. Complete response was seen in 92 (74.2\%) patients, partial response in $15(12.1 \%)$ patients, stable disease $9(7.3 \%)$ patients and progressive disease 8 (6.5\%) patients.On sub-group analysis complete response was seen in 49 (79\%) patients in morning arm versus 43 (69.4\%) patients for evening. Partial response was achieved in $7(11.3 \%)$ versus $8(12.9 \%)$ patients in morning arm, evening arm respectively but the difference was statistically insignificant $(\mathrm{p}=0.958)$ (Figure 1).

In our study, $83.8 \%$ and $79 \%$ had disease free survival at the end of 6 months (Table 5).The 2- year overall survival was found to be $69.4 \%$ in the morning arm and $53.2 \%$ in the evening arm (Figure 2).

Table 1:- Onset and duration of radiation induced oral mucositis.

\begin{tabular}{|l|l|l|l|}
\hline $\begin{array}{l}\text { Onset of } \\
\text { Mucositis }\end{array}$ & $\begin{array}{l}\text { Morning Arm } \\
\text { n (percentage) }\end{array}$ & $\begin{array}{l}\text { Evening Arm } \\
\text { n (percentage) }\end{array}$ & p-value \\
\hline Week 1 & $0(0 \%)$ & $0(0 \%)$ & - \\
\hline Week 2 & $32(51.6 \%)$ & $52(83.9 \%)$ & $\mathbf{0 . 0 0 0}$ \\
\hline Week 3 & $42(67.7 \%)$ & $56(90.3 \%)$ & $\mathbf{0 . 0 0 2}$ \\
\hline Week 4 & $53(85.5 \%)$ & $57(91.9 \%)$ & 0.256 \\
\hline Week 5 & $56(90.3 \%)$ & $60(96.8 \%)$ & 0.144 \\
\hline Week 6 & $57(91.9 \%)$ & $60(96.8 \%)$ & 0.243 \\
\hline Week 7 & $55(88.7 \%)$ & $61(98.4 \%)$ & 0.028 \\
\hline
\end{tabular}

Table 2:- Severity of oral mucositis at the end of treatment.

\begin{tabular}{|l|l|l|l|}
\hline Severity of Mucositis & $\begin{array}{l}\text { Morning Arm } \\
\text { n=62 (percentage) }\end{array}$ & $\begin{array}{l}\text { Evening Arm } \\
\text { n=62 (percentage) }\end{array}$ & p- value* \\
\hline Grade 0 & $05(8.1 \%)$ & $01(1.6 \%)$ & 0.207 \\
\hline Grade 1 & $12(19.4 \%)$ & $04(6.5 \%)$ & 0.058 \\
\hline Grade 2 & $28(45.2 \%)$ & $20(32.3 \%)$ & 0.197 \\
\hline Grade 3 & $16(25.8 \%)$ & $29(46.8 \%)$ & $\mathbf{0 . 0 2 4}$ \\
\hline Grade 4 & $01(1.6 \%)$ & $08(12.9 \%)$ & $\mathbf{0 . 0 1 7}$ \\
\hline
\end{tabular}

*Fisher Exact Test

Table 3:- The median time to develop Grade 3 or 4 oral mucositis.

\begin{tabular}{|l|l|l|l|}
\hline & $\begin{array}{l}\text { Morning Arm } \\
\text { n=62 patients }\end{array}$ & $\begin{array}{l}\text { Evening Arm } \\
\text { n=62 patients }\end{array}$ & p-value* \\
\hline Median Time & 5.8 weeks & 4.7 weeks & $\mathbf{0 . 0 1 3}$ \\
\hline
\end{tabular}

*Independent t-test 


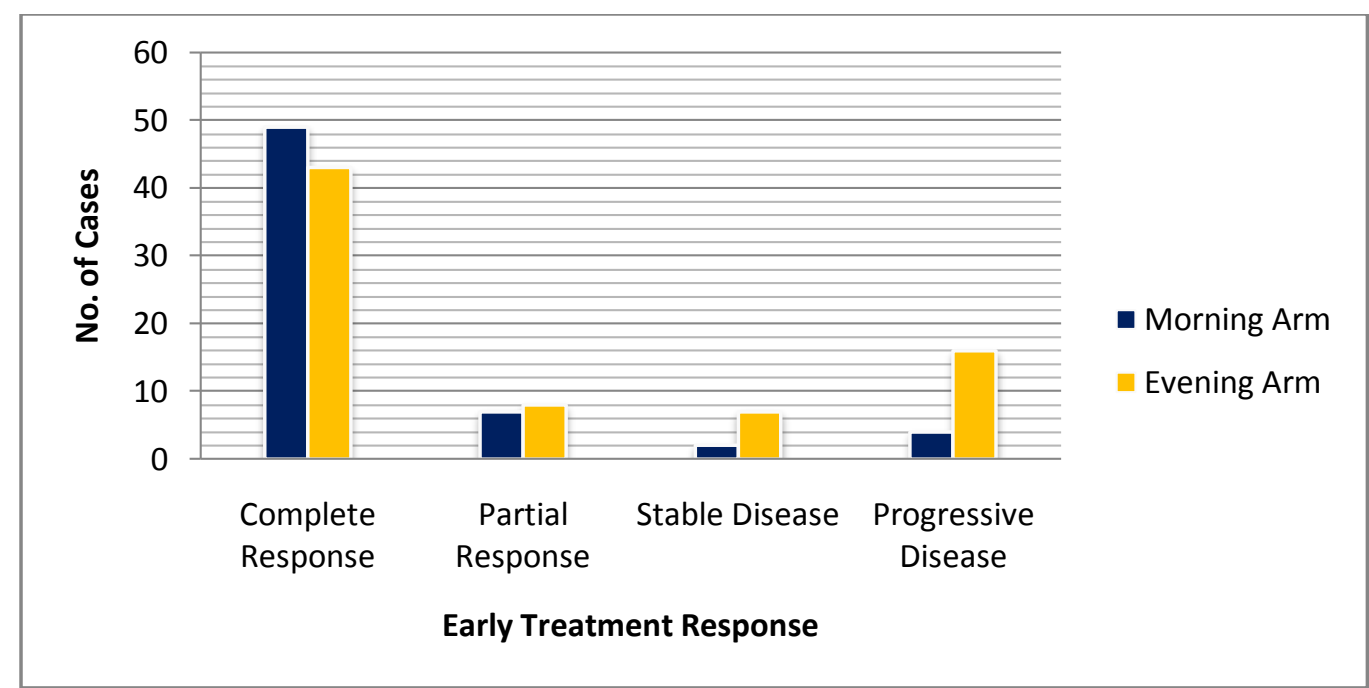

Figure 1:- Early Treatment Response between the two arms (1 month post RT).

Table 4:- Late Treatment Response at 6 Month Post RT.

\begin{tabular}{|l|l|l|}
\hline Type Of Response & $\begin{array}{l}\text { Morning Arm } \\
\text { No. of patients (\%) }\end{array}$ & $\begin{array}{l}\text { Evening Arm } \\
\text { No. of patients (\%) }\end{array}$ \\
\hline Disease Free Survival (DFS) & $52(83.8 \%)$ & $49(79.0 \%)$ \\
\hline Survival with Disease (SWD) & $03(4.8 \%)$ & $05(8.0 \%)$ \\
\hline Overall Survival (OS) & $55(88.6 \%)$ & $54(87.0 \%)$ \\
\hline
\end{tabular}

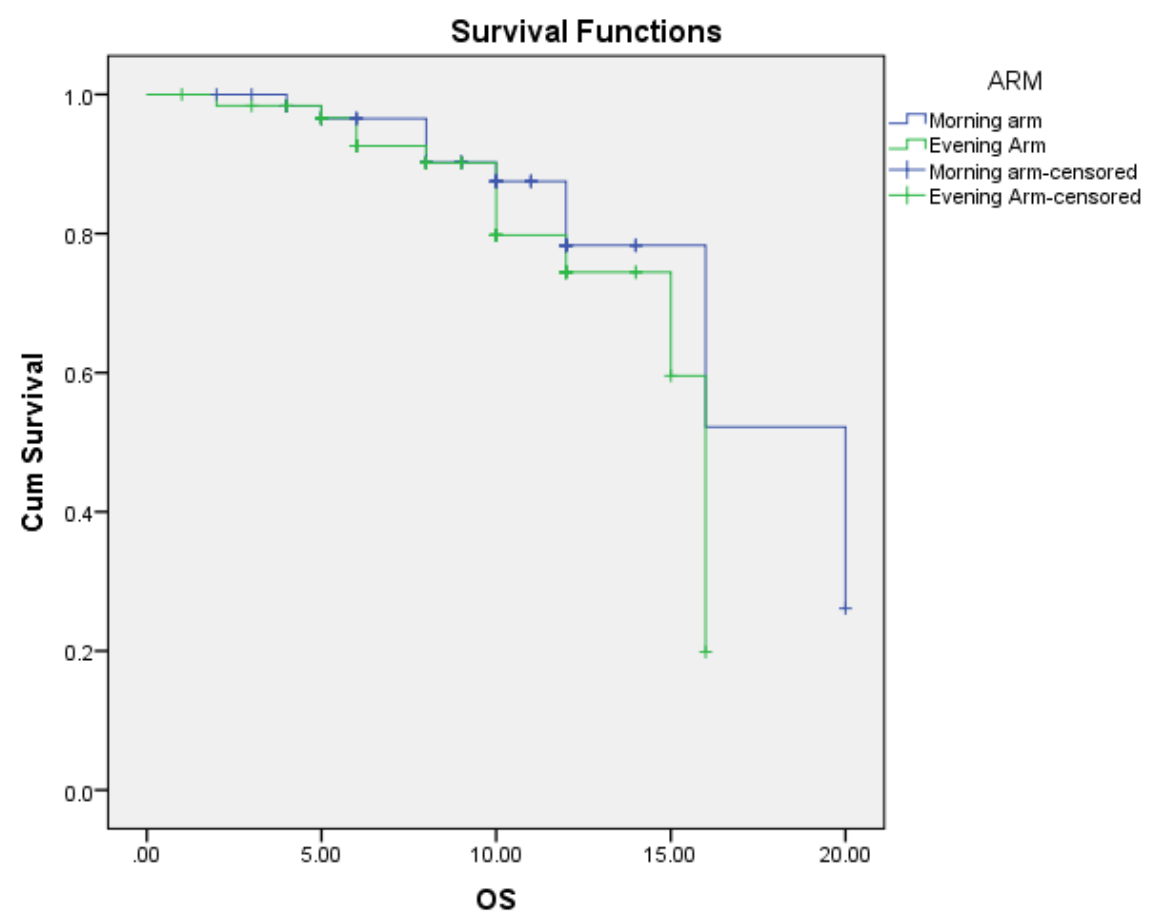

Figure 2:- Kaplan Meier overall survival curves at 2 years between the two arms.

\section{Discussion:-}

\section{Patient and tumor characteristics:}

In the present study the median age at diagnosis of head and neck cancer was found to be 54 years (range $=31-68$ years). The median age for male patients being 52 years and female patients being 60 years. The analysis of study done in US population by Vigneswaran $\mathrm{N}$ et al showed that the median age at diagnosis of head and neck was 58 
years for men and 61 years for women. ${ }^{14}$ In regard to the age distribution among the two arms, it was found that the maximum number of patients were in the age group of 51 to 60 years which was found similar to the study conducted byShenoi $\mathrm{R}$ et al (38.7\% and $27.8 \%$ respectively). ${ }^{15}$

Out of 124 patients accrued for the study, 84 (67.7\%) were males and 40 (32.2\%) were female with a male to female ratio of 2.1:1. In both the arms male predominance was seen ( $\mathrm{p}$ value $=0.124$ ). Pinholt et al observed almost equivalent numbers between men and women $(1.2: 1){ }^{16}$

In the present study $68.5 \%$ patient were smokers or had previous history of smoking and $31.5 \%$ were never smokers ( $\mathrm{p}$ value $=0.176$ ). Koyanagi YN et al analyzed systematic review of previous epidemiological studies for cigarette smoking and head and neck cancer. Four of five cohort studies and 11 of 12 case-control studies showed a strong positive association between cigarette smoking and head and neck cancer. ${ }^{17}$ In contrary to the study in Southern India by Rekha R showed $60.4 \%$ of head and neck cancer associated with patients having no habits or risk factors. ${ }^{18}$

In this study the median Karnofsky performance status was found to be $80 \%$ which was similar to the study conducted by Visacri MB et al where the median KPS was found to $90 \%$ in these patients. ${ }^{19}$

In the present study the most common primary site was found to be carcinoma nasopharynx $36.6 \%$ followed by carcinoma of oral cavity $26.6 \%$ and hypopharynx $13.7 \%$. A study by Kataki et al, showed that nasopharyngeal carcinoma is uncommon in the Indian subcontinent except in the Northeastern part of the country. ${ }^{20}$

\section{Treatment Toxicity :}

In the present study the onset of radiation induced mucositis began at the end of second week, $51.6 \%$ in the morning arm and $83.9 \%$ in the evening arm. The results were found to be statistically significant. $(\mathrm{p}=0.000)$. The peak of radiation induced oral mucositis was seen at the end of 5 weeks in the morning arm and 7 weeks in the evening arm. This is in consistent with the observation by Mohanti BK et al, that the radiation starts appearing towards $2^{\text {nd }}$ and $3^{\text {rd }}$ week of conventional radiotherapy and reach the maximum at a cumulative dose of 50Gy and gradually decline in classical shrinking field technique. ${ }^{21}$ A study by Baker DJ observed that that mucosal erythema occurs in the first week in patients treated with standard $200 \mathrm{cGy}$ of daily fractionated radiotherapy programs, patchy or confluent mucositis peaks during the fourth to fifth weeks of treatment with the same dose of radiation. With daily fractionated programs of $<200 \mathrm{cGy}$, the severity of mucositis is expected to be low. However, in accelerated radiotherapy programs, mucositis peaks within 3 weeks of the radiation therapy. ${ }^{22}$

In this study the severity of radiation induced oral mucositis was found in the morning arm with $8.1 \%$ grade 0 , $19.4 \%$ grade $1,45.2 \%$ grade $2,25.8 \%$ grade 3 and $1.6 \%$ grade 4 . In the evening arm, it was $1.6 \%$ grade $0,6.5 \%$ grade $1,32.3 \%$ grade $2,46.8 \%$ grade 3 and $12.9 \%$ of grade 4 . The results with the published work of Bjarnason et al demonstrated a significant reduction of incidence of oral mucositis for the morning group ( $\mathrm{p}=0.024)$ when compared to patients receiving radiotherapy in the afternoon. ${ }^{23}$ The results of the study by Bashir et al were similar with $28.6 \%$ patients in the morning group compared to $43.7 \%$ patients in the evening group developing grade 3 mucositis and the severe mucositis free interval (SMFI) was 33 days compared to 22 days in favour of the morning arm. ${ }^{24} \mathrm{Chan} S$ et al in their meta-analysis showed morning treatment was significantly associated with a $19 \%$ decreased risk of developing grade III/IV oral mucositis (risk ratio $0.81,95 \%$ confidence interval $0.66-0.99, \mathrm{p}=0.04$ ). ${ }^{25}$

In the present study the median time to develop Grade 3 or 4 mucositis was found to be 5.8 weeks in the morning arm and 4.7 weeks in the evening arm. The similar results was seen in the study conducted by Kuriakose et al, the median time to develop grade 3 or 4 oral mucositis was found to be 6 weeks in the morning arm and 5 weeks in the evening arm. ${ }^{26}$

The impact of smoking on oral mucositis has been studied extensively. In our study, it was found that patients who were smokers or had previous history of smoking had significant grade 3 oral mucositis and the p value was found to be significant $(\mathrm{p}=0.005)$. This was in contrary to the study by Bjarnason et al where it was seen that there was apparent reduction in oral mucositis in patients who smoked during therapy. ${ }^{23}$ This discrepancy may be due to the westernized life style in developed countries and lack of oral hygiene in developing country like India. A study conducted by Szeszko B et al showed that Grade III/IV acute mucositis was observed in $43.5 \%$ of patients and the percentage of patients with grade III/IV acute mucositis was similar in smokers and non-smokers $(46 \% \mathrm{vs} .42 \%, \mathrm{p}=$ $0.71){ }^{27}$ 


\section{Treatment Response:}

In our study early response assessment was done 1 month after the completion of treatment, which showed patients with Stage 1 and 2, complete response was seen in $92(74.2 \%)$ patients, partial response in $15(12.1 \%)$ patients, stable disease $9(7.3 \%)$ patients and progressive disease $8(6.5 \%)$ patients The overall survival at the end of 2 years was $85 \%$. Truong MT et al analyzed the outcome and survival in 15 head and cancer carcinoma patients in early stage undergoing definitive RT, with a median follow-up of 28 months (range, 6-44 months), 13 patients achieved loco regional control. Four of 15 patients developed distant metastases. The overall survival rate at 1 and 2 years was $93 \%$ and $86 \%$, respectively. ${ }^{28}$ This in contrary to a study conducted by Krstevska $\mathrm{V}$ et al where complete primary response was achieved in 31 of 51 patients treated with conventional fractionation. The 2-year loco regional control rate was $41.0 \%$, overall survival rate at two years was $50.2 \% .^{29}$

In our study,complete response was seen in $26(41.9 \%)$ patients in morning arm versus $28(45.2 \%)$ patients for evening. Partial response was achieved in $16(25.8 \%)$ versus $14(22.6 \%)$ patients in morning arm, evening arm respectively but the difference was statistically insignificant $(\mathrm{p}=0.958) .{ }^{30} \mathrm{~A}$ study by Bjarnason et al showed that the loco regional control was achieved in $68.5 \%$ of patients in the morning arm and $62.9 \%$ in the evening arm and 2year overall survival was found to be $61.1 \%$ and $64.1 \%$ respectively. In our study the 2 -year overall survival was found to be $69.4 \%$ in the morning arm and $53.2 \%$ in the evening arm. ${ }^{23}$ There is lack of studies on tumor response with respect to chronobiology.

\section{Conclusion:-}

In the morning arm the incidence of oral mucositis was observed to be significantly delayed and the duration of mucositis was also significantly shorter as compared to the evening arm with statistically significant difference in severity of mucositis between the two arms. Past history of smoking increases the severity of oral mucositis. The results of this study substantiate the fact that the radiation treatment delivered in the morning hours is associated with lesser incidence of Grade 3 or 4 mucosal toxicities.After treatment number of the morning arm patients' complete response was higher than evening arm patients. Through large randomized trials are lacking, there is sufficient clinical evidence signifying the importance of utilizing chronotherapy as an important treatment strategy.Since there is no active interventional or pharmacological measure to minimize normal tissue toxicity, chronomodulated radiotherapy would be a feasible and cost effective treatment strategy that can be put into clinical practice.

\section{References:-}

1. Semple CJ, Sullivan S, Dunwoody L and Kernohan WG. (2004): Psychosocial interventions for patients with head and neck cancer. Cancer Nursing. 27(6):434-40.

2. Calcaterra TC and Juillard GJ. (1995): Oral cavity and hypopharynx - head and neck cancer. In: Haskell CM, Berek JS, editors. Cancer treatment. WB Saunders Co; Philadelphia: .p.726-32.

3. Bray F, Ferlay J, Soerjomataram I, Siegel RL, Torre LA and Jemal A. (2018): Global cancer statistics 2018: GLOBOCAN estimates of mortality worldwide for 36 cancers in 185 countries. CA Cancer J Clin. 68(6):394424.

4. Mendenhall WM, Werning JW and Pfister DG. (2015): Cancer of the head and neck. In: DeVita VT, Hellman S, Rosenberg SA, $10^{\text {th }}$ ed. Cancer: Principals and practice of Oncology. Philadelphia: Wolters Kluwer; p. 42224.

5. Cognetti DM, Weber RS and Lai SY. (2008): Head and neck cancer: an evolving treatment paradigm. Cancer.113(70):1911-32.

6. Lalla RV, Brennan MT and Schubert MM. (2011) :Oral complications of cancer therapy. In: Yagiela JA, Dowd FJ, Johnson BS editors. Pharmacology and therapeutics for dentistry. 6th ed. St. Louis: Mosby Elsevier; p.78298.

7. Sonis ST, Elting LS, Keefe D, Peterson DE, Schubert M, Hauer-Jensen M, et al. (2004): Perspectives on cancer therapy induced mucosal injury: pathogenesis, measurement, epidemiology and consequences for patients. Cancer.100(9):1995-2025.

8. Lalla RV, Bowen J, Barasch A, Elting L, Epstein J, Keefe DM, et al. (2014): MASCC=ISOO Clinical practice guidelines for the management of mucositis secondary to cancer therapy. Cancer. 6(1):1453-61.

9. Bjarnason GA, Jordan RCK and Sothern RB. (1999): Circadian variation in the expression of cell-cycle proteins in human oral epithelium. Am J Pathol. 154(2):613-22. 
10. Kuriakose VG, Jayakumar K, Anand A, Krishnan AR and Somasekharan D. (2016): Impact of chronomodulated radiotherapy on acute skin toxicity in chest wall irradiated breast cancer patients - A single institution analysis. Onco Expert. 2(1):1-7.

11. Bertoli C, Skotheim JM and Robertus AM. (2013): Control of cell cycle transcription during G1 and S phases. Nat Rev Mol Cell Biol.14(8):518-28.

12. Chen MJ, Tang WY, Hsu CW, Tsai YT, Wu JF and Lin CW. (2017): Apoptosis induction in primary human colorectal cancer cell lines and retarded tumor growth in scid mice by sulforaphane. Cell Death Discov.3(1):17014.

13. Schernhammer ES, Laden F and Speizer FE. (2003): Night-shift work and risk of colorectal cancer in the nurses' health study. J Natl Cancer Inst.95(11):825-8.

14. Vigneswaran N and Williams MD. (2014):Epidemiological Trends in Head and Neck Cancer and Aids in Diagnosis.Oral Maxillofac Surg Clin North Am. 26(2): 123-141.

15. Shenoi R, Devrukhkar V, Chaudhuri, Sharma BK, Sapre SB and Chikhale A. (2012): Demographic and clinical profile of oral squamous cell carcinoma patients: A retrospective study. Indian J Cancer.49(1):21-6.

16. Pinholt EM, Rindum J and Pindborg JJ. (1997): Oral cancer: A retrospective study of 100 Danish cases. Br J Oral Maxillofac Surg.35(1):77-80.

17. Koyanagi YN, Matsuo K, Ito H, Wakai K, Nagata C, Nakayama T, et al. (2016) : Cigarette smoking and the risk of head and neck cancer in the Japanese population: a systematic review and meta-analysis. Jpn J Clin Oncol.46(6):580-95.

18. Rekha R, Reddy MVV and Reddy PP. (2013):Epidemiological studies of head and neck cancer in south Indian population. Res Cancer Tumor.2(2):38-44.

19. Visacri MB, Ferrari GB, Pimentel R, Rosiane D, Lopes AF, Lima CSP, et al.(2015): Evaluation of the quality of life of patients before treatment of squamous cell carcinoma of the head and neck by means of chemoradiotherapy. Contemp Oncol.19(2):148-53.

20. Kataki AC, Simons MJ, Das AK, Sharma K and Mehra Narinder K. (2011): Nasopharyngeal carcinoma in the northeastern states of India. Chin J Cancer.30(2):106-13.

21. Mohanti BK, Bahadur, Lal P, Gairola M and Rath GK. (2002): Cancers of Head and Neck. In: Rath GK, Mohanti BK, editors. Textbook of Radiation Oncology. $1^{\text {st }}$ ed. India: Elsevier; p.131.200.

22. Baker DG. (1982): The radiobiological basis for tissue reactions in the oral cavity following therapeutic Xirradiation. Arch Otolaryngol.108(1):21-24.

23. Bjarnason GA, Mackenzie RG, Nabid A, Hodson ID, El-Sayed S, Grimard L, et al.(2009): Comparison of toxicity associated with early morning versus late afternoon radiotherapy in patients with head-and-neck cancer: a prospective randomized trial of the national cancer institute of canada clinical trials group. Int J Radiat Oncol Biol Phys.73(1):166-72.

24. Bashir I, Chufal KS, Thakwani A, Bhatnagar A, Alam A and Ghosh D. (2014): Prospective study evaluating impact of morning versus evening radiotherapy on mucositis in patients undergoing head and neck intensitymodulated radiotherapy with concurrent chemotherapy. J Young Med Res.1(1):1-7.

25. Chan S, Rowbottom L, McDonald R, Bjarnason GA, Tsao M, Danjoux C, et al. (2017): Does the time of radiotherapy affect treatment outcomes? A review of the literature. Clin Oncol.29(4);231-8.

26. Kuriakose VG, Anand AS, Jayakumar K, Radhakrishnan A and Meloot SS. (2016): Influence of circadian rhythm in radiation induced mucositis in head and neck malignancies. J Pharm.6(11):21-6.

27. Szeszko B, Osowiecka K, Rucińsk M, Teśluk EW, Gliński K and Kępka L. (2015): Smoking during radiotherapy for head and neck cancer and acute mucosal reaction. Rep Pract Oncol Radiother.20(4):299-304.

28. Truong MT, Saito N, Ozonoff A, Wang J, Lee R, Qureshi MM, et al. (2011): Prediction of locoregional control in head and neck squamous cell carcinoma with serial ct perfusion during radiotherapy.Am $\mathrm{J}$ Neuroradiol.32(7):1195201.

29. Sukumaran S, Almon RR, Dubois DC and Jusko WJ. (2010):Circadian rhythms in gene expression: relationship to physiology, disease, drug disposition and drug action. Adv Drug Deliv Rev.62(9):904-17.

30. Heng C and Rossi EP. (1995): A report on 222 cases of oral squamous cell carcinoma. Mil Med.160(1):319-23. 